\title{
Economic evaluation of small wind turbines and hybrid systems for residential use: The case of Romania
}

Mihail Predescu

predescu@aeolusenergy.ro

SC Aeolus Energy International,

Bucharest, Romania

\begin{abstract}
Renewable electricity generating systems are gaining ground in residential sector for the purpose of diminishing the electricity bills or to reaching some degree of energy independence. The decision to invest in small wind turbines or hybrid energy generation technologies should be based on an economic evaluation of money invested in such systems. LCOE calculation for local technologies of choice for residential energy generation is a very reliable figure for deciding whether the investment can bring financial satisfaction and for selecting which type of technology is the best suited for a specific location.
\end{abstract}

KEYWORDS: Renewable energy. Small wind turbines. Levelized cost of energy. LCOE. 


\section{INTRODUCTION}

Renewable energy conversion technologies are becoming more and more popular in locally energy generation for residences contributing to distributed energy production strategy. Conventional energy resources are becoming scarce or should be imported from abroad creating uncomfortable dependency and high degree of unpredictability of availability and price. Cleaner energy production is another hot topic at world level which determined the policy makers to promote legislation for boosting the renewable energy technologies penetration. Government incentives, either investment subsidies or feed-in tariff, are good reasons for deciding an investment in small wind or other renewable energy technology. Small wind turbines, photovoltaic or hybrid energy generating systems are currently the common options for residential applications, both ongrid and off-grid, since the primary resources are ready available at the very location. Technology selection and final decision should be based on economic assessment of the investment, otherwise the financial result could be far from expectations.

\section{SMALL WIND TURBINE MARKET}

Wind conversion technology is evolving at high rates at world scale, registering two digits grows rate, and the prediction is to reach $800 \mathrm{GW}$ in 2020 and $2000 \mathrm{GW}$ by 2030 . The economic aspects of investment in utility scale wind technology are well investigated for the simple reason that it is a huge industry requiring large amount of money for which accurate predictions are mandatory.

Small wind turbines are addressing individuals or small consumers at residential level. This industry is growing fast two. At the end of 2012 the cumulative figure of installed small wind systems was more than 806.000 units worldwide (GANGER; PITTELOUD, 2014), which is $10 \%$ increases compared to the previous year.

Economic evaluation of small wind systems is not quite well addressed yet for two reasons: the investment is much smaller than large wind systems and variability of the wind conditions at a potential site requests a specific approach. Additionally, the specific cost of small wind turbines systems on the market is highly variable, depending on producers, quality of components, cost of instalment and other local costs.

\section{METHOD OF COMPUTING LCOE}

Computation of Levelised Cost of Energy (LCOE) is the common method for estimation and comparison of investment performance in alternative energy generation technologies (SHORT; PACKEY, 1995). Specifically, LCOE is a prediction of the specific energy production cost (e.g. $€ / \mathrm{kWh}$ ), as constant value of income/saving over a period (lifetime) of operation, expressed in present value of money. The general formula is (SHORT; PACKEY, 1995; CORY; SCHWABE, 2009):

$$
L C O E=\frac{\sum_{n=0}^{N} \frac{C_{n}}{(1+d)^{n}}}{\sum_{n=1}^{N} \frac{Q_{n} \times(1+r)^{-1}}{(1+d)^{n}}}
$$




$$
C_{n}=I_{n}+O_{n}+F_{n}
$$

Where:

$\mathrm{Cn}$-cost of system operation in year $\mathrm{n}$ of operation

In -investment in year $\mathrm{n}$ of operation (I0-initial investment)

Fn-cost of fuel in year $n$

On-O\&M cost in year $n$ of operation

Qn -energy production in year $\mathrm{n}$ of operation

d -discount rate

$r$ - yearly degradation rate of the system

$\mathrm{N}$-number years of analysis (usually lifetime)

In LCOE calculations two discount rates are used (SHORT; PACKEY, 1995): nominal $(\mathrm{dn})$, real $(\mathrm{dr})$ and additionally inflation rate (e), The relationship between those three discount rates is:

$$
\left(1+d_{n}\right)=\left(1+d_{r}\right)(1+e)
$$

\section{ECONOMIC ANALYSIS OF ALTERNATIVE TECHNOLOGIES}

\section{BASIC ASSUMPTIONS}

The analysis of each technology options for electricity generation is based on cash flow calculation on lifetime of the investment for each case. Selection of the discount rate depends on the dimension of the investment and the type of the investor (SHORT; PACKEY, 1995). In commercial and residential sector investments, most experts recommend to use the opportunity cost of capital (SHORT; PACKEY, 1995), which is the best rate of return of the invested money. The investment in residential sector is intended to bring saving rather than gains. For this reason, a good alternative for money investment is in bank deposit which brings an annual rate of return, but this option could be unreliable in case of financial turmoil. Where the legal framework offers incentives for using renewable energies in residential applications, the financial gain is possible, but in the analysis incentives are not considered, because they are either locally applied and mostly uncertain on long term. In the subsequent analysis the discount rate considered is the highest interest paid by Romanian banks to the account holder, which is at $4 \% /$ year. Whether the investment in renewable energy conversion technology is only for saving purposes, or for home use of the produced energy, the taxes are not applicable. The analysis is devoted to the most common used residential energy generating technologies, both for wind ongrid and for off-grid applications: wind, photovoltaic and diesel/gasoline generators.

The period of analysis for LCOE calculations is 15 years which is common for wind turbines and photovoltaic systems and it is also applied for diesel/gasoline generators, just to have a common basis for comparing their viability as investment alternatives for local electricity production. 


\section{SMALL WIND TURBINES ON-GRID}

For evaluating the energy savings which can result from using different technologies for on-grid systems, the reference figure is household energy purchasing price. The source of energy prices in EU-28 is (EUROSTAT, 2011): in Romania-0,132€/kWh, maximum EU 28-0,3 €/kWh and minimum EU28-0,092 $€ /$ kWh.

Figure 1 - Layout of on-grid wind turbine system

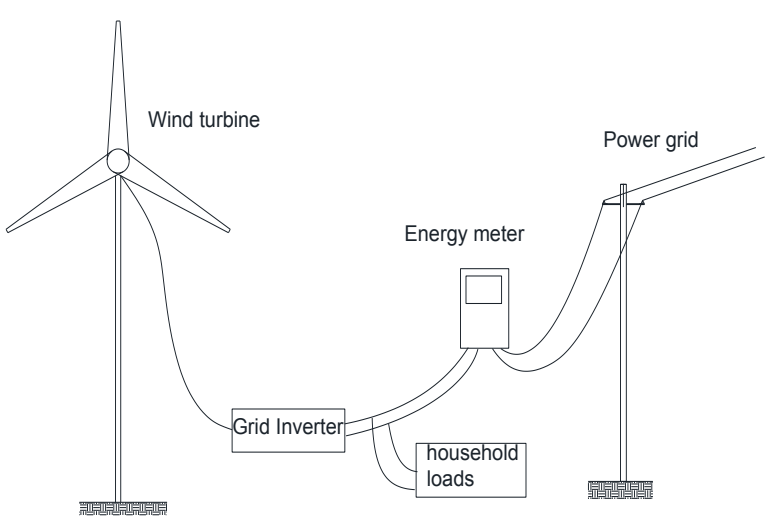

The general layout of grid-connected small wind turbine is in Figure 1. This type of system is implemented for diminishing the energy bill of a residence. The small wind turbine is connected to the power grid via a dedicated inverter which maximizes the power transfer, via MPPT algorithm or predefined power curve.

A typical power curve of a 2,5kW good wind turbine with rated power at 12 $\mathrm{m} / \mathrm{s}$ wind speed, given in Figure 2, is the basis in the following analysis. For having a general approach, easily to be extrapolated, the following calculations are performed on normalized $1 \mathrm{~kW}$ wind turbine derived from the $2,5 \mathrm{~kW}$ turbine power curve, keeping the same power coefficient Cp curve.

Specific investment cost in small wind turbine systems shows large variations depending on producer, quality of the components, size, local manpower costs, and location of the installation. This specific cost ranges from 2000 to $7000 € / \mathrm{kW}$, resulting from different sources, see e.g. (WIND-POWERPROGRAM, [2016]; WORLD WIND ENERGY ASSOCIATION, 2013). O\&M costs are variable and the data available is not reliable. Most sources consider the O\&M costs at $1-3 \%$ of the initial investment as reasonable (WIND-POWER-PROGRAM, [2016]). In the following calculations O\&M is considered $2 \% / y e a r$. 
Figure 2 - Typical 2,5kW wind turbine power curve and normalized power curve

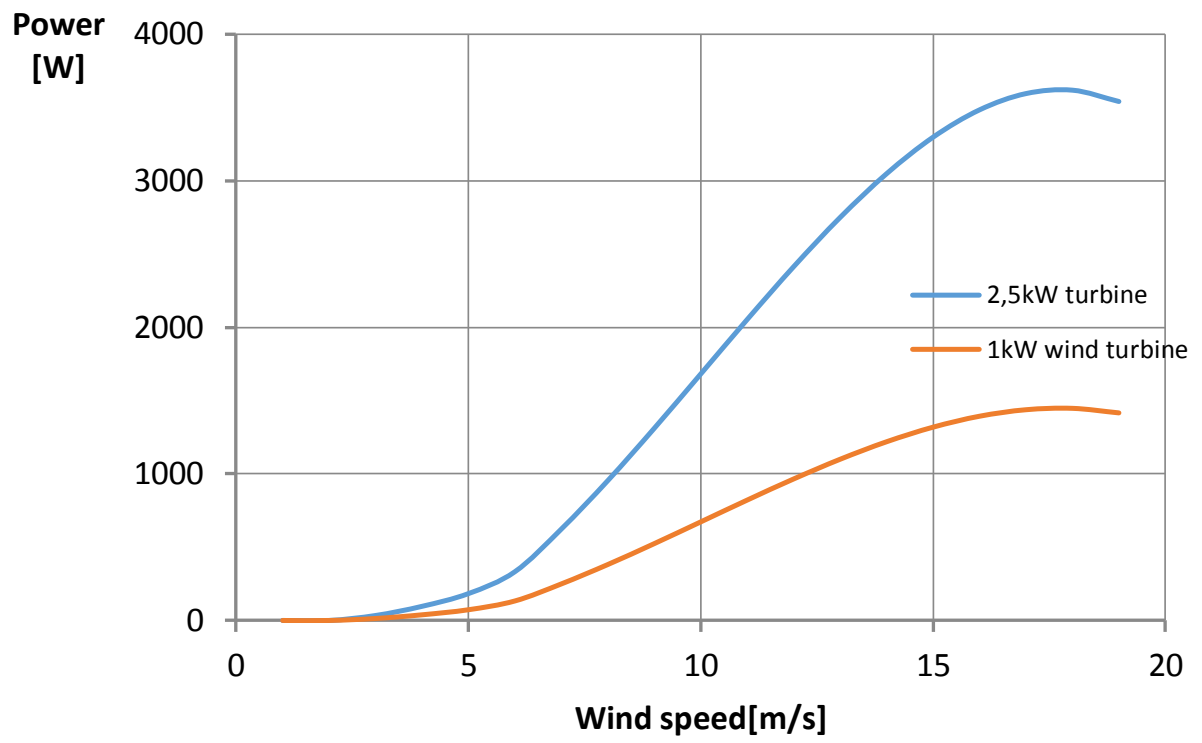

Figure 3 - LCOE for on-grid wind turbines and EU28 household energy prices

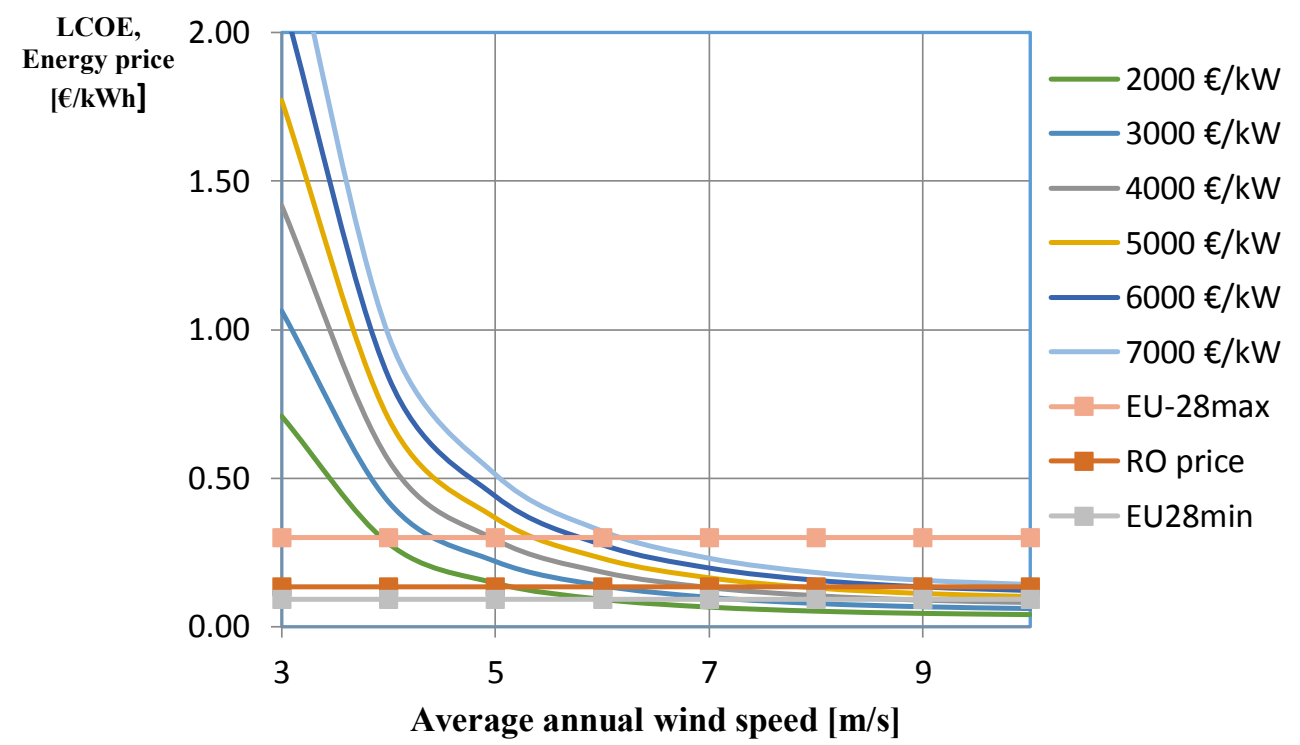

The LCOE family curves in Figure 3 are computed versus annual average wind speeds, at different specific investment values. On the same chart it is the household energy purchasing prices in EU as references. The financial viability in small wind investment is in the region where LOCE curve, computed for a specific investment value, is lower than the household energy price at the implementation location. 
Figure 4 - Investment viability of on-grid wind turbines in Romania-energy household price is $0,132 € / \mathrm{kWh}$

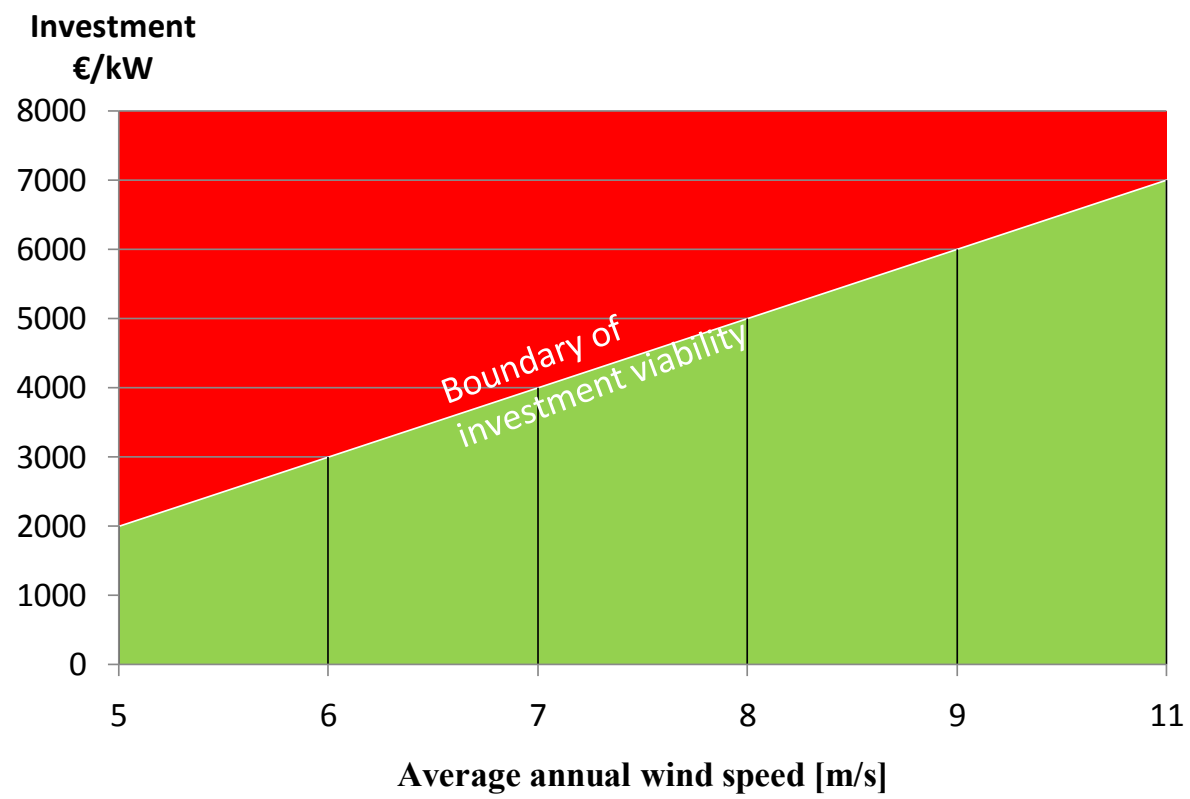

Break-even point for a specific investment value is at the intersection of the respective LCOE curve with the line representing the household energy price at the implementation location. Beyond this point, towards higher wind speeds, the savings obtained when using small wind technology brings tax free profit/savings on long term to the investor.

In countries where the household energy price is lower, the financial viability can be reached at smaller specific investment costs and higher annual average wind speed which limits the geographical area where the grid-connected small wind systems can be efficient.

More detailed analysis of the Romanian case is in Figure 4 where the household energy price is around $0,132 € / \mathrm{kWh}$ which is well below $0,2 € / \mathrm{kWh}$ EU average. The investment in small grid-connected wind turbines can be attractive where the annual average wind speed is above $5 \mathrm{~m} / \mathrm{s}$ at the lowest specific investment cost. This type of project is financially attractive in the green region of Figure 4, below the boundary investment viability curve on the same graph.

\section{OFF-GRID RESIDENTIAL ENERGY SYSTEMS}

For off-grid residential generating systems the approach is different. In this situation the energy price is not depending on the energy market or regulations of the national authorities, as it is the Romanian case. The investor should look after the most convenient technology which can result in lowest cost of energy locally produced.

Three technologies are examined, which are, in fact, the most common solutions implemented so far: small wind turbines, PV systems and gasoline generators. In many cases, the best option is to have a hybrid system which is the combination of these three technologies. 
Figure 5 - Layout of a typical off-grid system

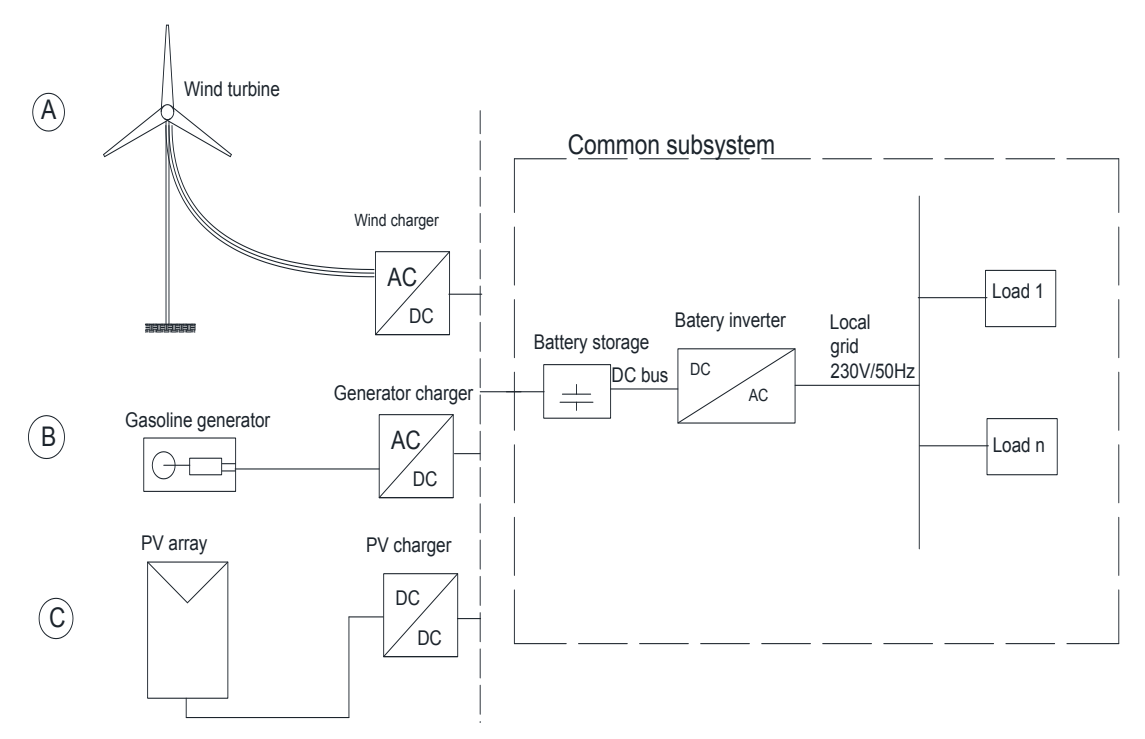

In Figure 5 is the general layout of an off-grid system. For such systems is mandatory to have a storage battery because the load profile cannot be fitted to the availability of the renewable energy sources, wind and sun. In case of diesel/gasoline generator the energy availability can be commanded by the instantaneous load, but the quality and availability of energy could suffer in some circumstances in systems without storage which is quite undesirable for the energy users.

Every energy source in Figure 5 is injecting energy into the battery bank via a dedicated power electronic adapter, specially designed for the input energy source and available on the market. The prices of these electronic adapters are quite similar or very close to each other.

The subsequent analysis is intended to make a comparison of technologies, and for this purpose each configuration is analysed separately, as follows:

Case A-system with small wind turbine;

Case B- system with gasoline generator;

Case C-Photovoltaic system.

\section{BASIC ASSUMPTIONS}

The analysis refers only to the investment which is in the variable part of the system, see Figure 5. For comparing the lifetime energy producing costs, LCOE, the approach is different from grid-connected systems. In on-grid applications, the reference is the household energy price, but in off-grid system the reference is the energy demand by the local loads which is in fact the purpose of the energy system.

For calculation of LCOE a base load of $1 \mathrm{~kW}$, which means $24 \mathrm{kWh} /$ day or $8760 \mathrm{kWh} /$ year, is considered for each technology. 
Cash flows for each case are calculated for 15 years lifetime, which is valid for wind and photovoltaic technology. But, for comparing the resulted LCOEs, the same period is applied to gasoline generators case with explanations below.

\section{DATA FOR SMALL WIND TURBINE}

The investment costs in case of small wind turbine technology is the same as in case of on-grid systems since the wind turbine is the same in both situations. The only difference could be in the price of grid inverter, which can be slightly more expensive than the wind charger. But the difference in overall investment costs is quite small and the impact on computations is negligible. The size of the wind turbine in computations is variable in this case, depending of the average wind speed which can generate in all situations an average base load of $1 \mathrm{~kW}$, meaning $8760 \mathrm{kWh}$ each year.

\section{DATA FOR PHOTOVOLTAIC SYSTEMS}

In case of photovoltaic system, the investment price, including VAT, is between 1400€/kWp(denoted PV-min) and 2000€/kWp (denoted PV-max) according to market investigation on home PV systems. The annual production of $1 \mathrm{kWp}$ of PV system is $1150 \mathrm{kWh} / \mathrm{kWp}$, average for Romania (RE.JRC.EC.EUROPA, [2016]). For providing $8760 \mathrm{kWh}$ each year, which is the energy reference for the analysis, the PV system should have 7,62kWp installed power.

Yearly degradation of PV module is considered $1 \%$, which is mostly accepted. O\&M cost estimations are variable but a reliable figure is at 19€/kWp/year (NREL, 2013).

\section{DATA FOR GASOLINE GENERATORS}

Many types of gasoline generators are available on the market showing great variations in quality, efficiency, nominal power and per kW price. For this study a market investigation has been performed on gasoline generators with nominal power ranging from $1 \mathrm{~kW}$ to $6,2 \mathrm{~kW}$, which are suited for household applications. During the market investigation 12 types of gasoline generators have been analysed.

The results are:

- Average specific price: $139,6 € / \mathrm{kW}(173,1 € / \mathrm{kW}$ including $24 \% \mathrm{VAT}$, in case of Romania);

- Fuel consumption:

- average: $\quad 0,70 \mathrm{l} / \mathrm{kWh}$ denoted GAS-ave

- $\min : \quad 0,48 \mathrm{l} / \mathrm{kWh}$, denoted GAS-min

- max: $\quad 0,94 \mathrm{l} / \mathrm{kWh}$-denoted GAS-max

- Gasoline price: 1,3 €/I (Romania-May 2015);

- Lifetime: 5000 to $10.000 h$ (average $8000 h$-almost one year). 
A gasoline generator cannot run full time for providing energy, since it requests often maintenance work and uses different fuel consumption at different loads. If running $24 / 7$ the generator should be replaced every year. A technical solution is to have a $5 \mathrm{~kW}$ generator running $20 \%$ of time for charging the battery at the most efficient operation regime for producing $8760 \mathrm{kWh} /$ year energy as explained above and the lifespan can be extended to 5 years, in average, instead of one year.

\section{RESULTS OF LCOE COMPUTATIONS}

For each of the three technologies for energy generation the specific cash flows are calculated and the results are LCOE curves versus annual average wind speed which is the sole variable in the analysis,

In

Figure 6 is a comparison between LCOEs of wind technology at different specific investment costs and gasoline generators. It is evident that the gasoline technology gives the highest LCOE, but initial investment is low. Wind technology is more financially efficient than gasoline generator for wind speed beyond 4,7 $\mathrm{m} / \mathrm{s}$ whatever the fuel consumption of the gasoline generators is.

Figure 6 - LCOE for wind vs. gasoline generators in off-grid systems

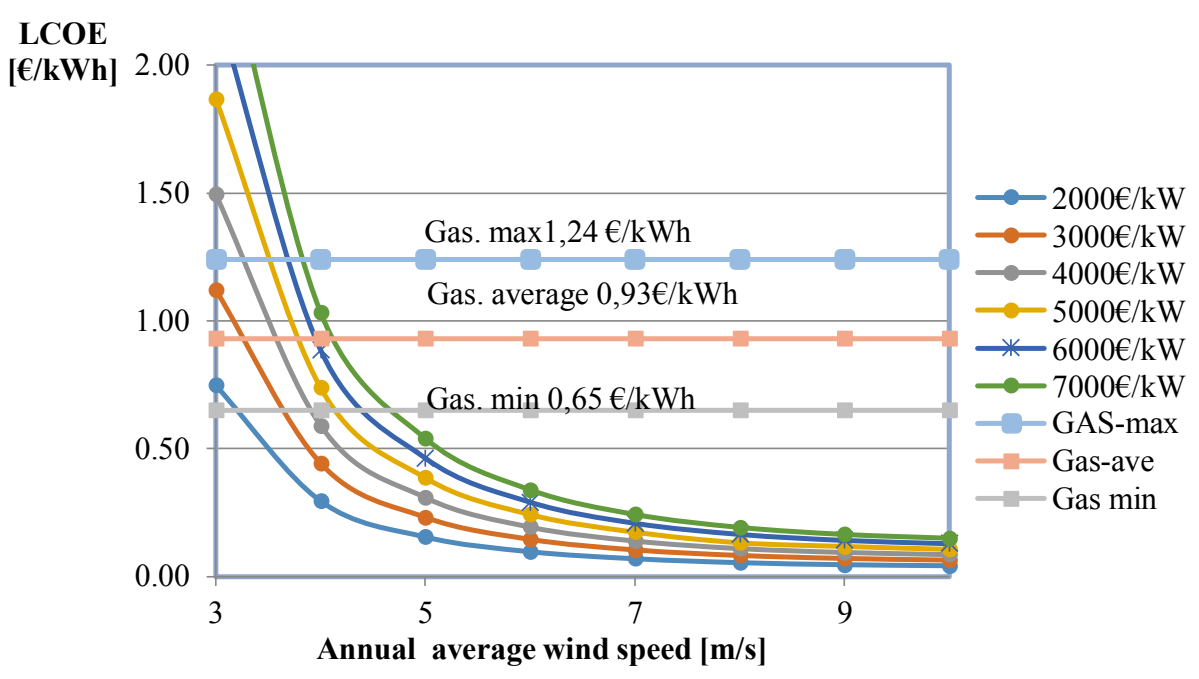

In Error! Reference source not found. is a comparison between LCOEs for small wind and PV technology in off--grid applications. The energy produced by wind technology gives better results for wind speeds above $5,5 \mathrm{~m} / \mathrm{s}$ at low specific investment cost For lower wind speeds, PV technology is the best option for both on-grid and off-grid energy systems. 
Figure 7 - LCOE for off-grid wind and PV technologies

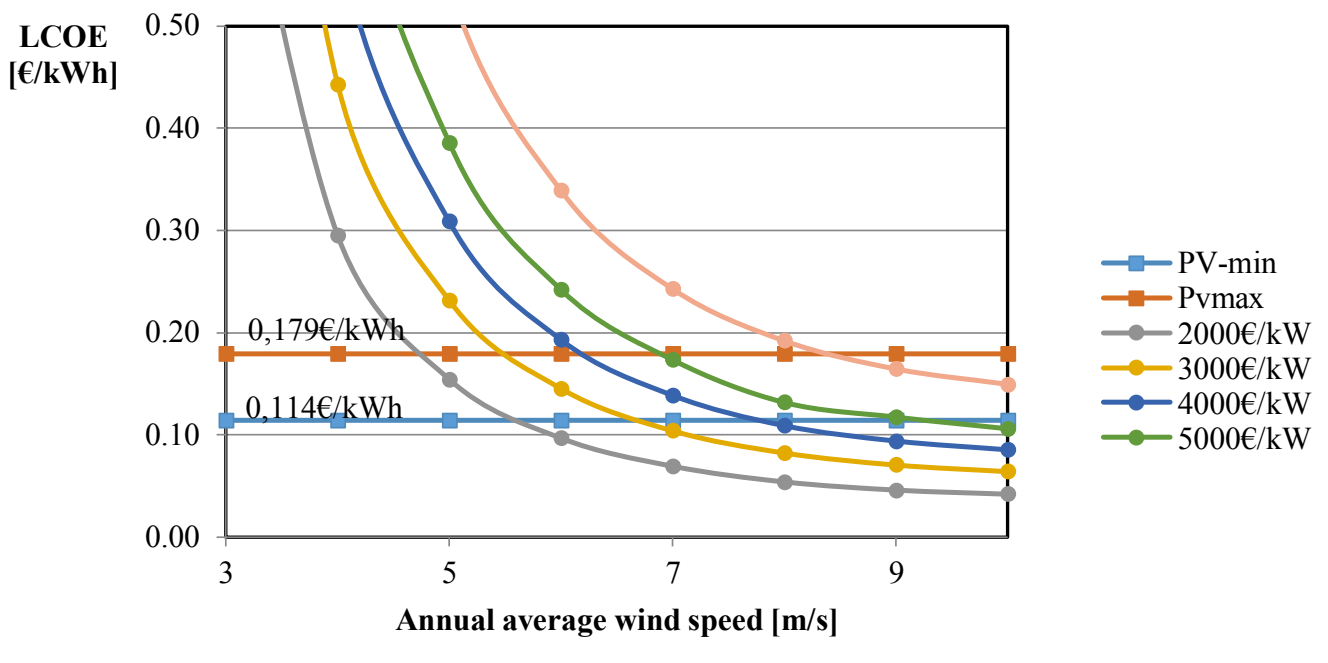

\section{CONCLUSIONS}

The LCOE computed for different technology options is a comprehensive value for deciding whether an investment in small wind residential system is viable or not at one location of the investment, or for selecting which type of technology is better suited for specific wind and solar resources. In case of ongrid systems, a good investment at one location is when computed LCOEs for alternative technologies are equal or less the household energy price on the market.

In case of off-grid generating systems, LCOE computed for every alternative technologies helps investor for selecting the technology which produces energy at the lowest cost. The analysis defines the boundaries within which an investment in renewable residential energy generating system can give positive financial results when is operating over a period, which is the lifetime. All the results presented in the paper can be used directly knowing local wind and solar resources and household energy price for deciding what the upper limit of specific investment cost of alternative options is which are financially viable or selecting the appropriate energy generation technology. 


\section{Avaliação econômica de pequenas turbinas eólicas e sistemas híbridos para uso residencial: $\mathbf{O}$ caso da Romênia}

\section{RESUMO}

Sistemas de geração de energia renovável estão a ganhar terreno no setor residencial com a finalidade de diminuir as contas de eletricidade ou para alcançar algum grau de independência energética. A decisão de investir em turbinas eólicas de pequeno porte ou tecnologias de geração de energia híbrida deve ser baseada em uma avaliação econômica de dinheiro investido em tais sistemas. O cálculo LCOE para as tecnologias locais de escolha para a geração de energia residencial é uma figura muito confiável para decidir se o investimento pode trazer satisfação financeira e para selecionar qual tipo de tecnologia é o mais adequado para um local específico.

PALAVRAS-CHAVE: Energia renovável. Pequenas turbinas eólicas. Custo nivelado de energia. LCOE. 


\section{REFERENCES}

CORY, Karlynn ; SCHWABE, Paul. Wind Levelized Cost of Energy: A Comparison of Technical and Financing Input Variables- Technical Report NREL/TP-6A24667. October 2009.

EUROSTAT. Half-yearly electricity and gas prices, first half of year.2011-13.

GANGER S.; PITTELOUD, J. Small Wind World Report 2014. World Wind Energy Association. March 2014.

IEC 61400-12-1-Wind turbines. Power performance measurement of electricity producing wind turbines

KOST, C. et al. Levelized Cost of Electricity Renewable Energy TechnologiesFraunhofer Institute for Solar Energy Systems. November 2013.

NREL. Distributed Generation Renewable Energy Estimate of Costs. updated August 2013.

RE.JRC.EC.EUROPA. From: <http://re.jrc.ec.europa.eu/pvgis/apps4/pvest.php>. 2016.

SHORT, Walter; PACKEY, Daniel J. ; Thomas Holt. A Manual for the Economic Evaluation of Energy Efficiency and Renewable Energy Technologies. March 1995. NREL/TP-462-5173.

WIND-POWER-PROGRAM . From: <http://www.wind-powerprogram.com/turbine economics.htm>. [2016].

WORLD WIND ENERGY ASSOCIATION. Small Wind World Report. 2013 
Recebido: 06 jun. 2016.

Aprovado: 04 ago. 2016.

DOI: $10.3895 /$ rbpd.v5n2.4045

Como citar: PREDESCU, M. Economic evaluation of small wind turbines and hybrid systems for residential use: The case of Romania. R. bras. Planej. Desenv.,Curitiba, v. 5, n. 2, p. 185-197, mai./ago. 2016.

Disponível em: <https://periodicos.utfpr.edu.br/rbpd>. Acesso em: XXX.

Correspondência:

Mihail Predescu

Str. Nicolae Teclu, Nr. 46-48, Sector 3, Bucharest, Romania.

Direito autoral: Este artigo está licenciado sob os termos da Licença CreativeCommons-Atribuição 4.0

Internacional. 